\title{
Visitors' Perception of the Effectiveness of Leptospirosis Health Hazard Warning Signage in Recreational Parks, Hulu Langat District, Malaysia
}

Mohd Shahrol Abd Wahil ${ }^{1}$, Sharifah Fazlinda Syed Nor ${ }^{1}$, Wong Chin Mun ${ }^{1}$, Norain Ahmad ${ }^{1}$, Noor Dalila Inche Zainal Abidin $^{1}$, Siti Rasidah Abd Ghani ${ }^{1}$, Lavanyah Sivaratnam ${ }^{1}$, Sharifah Ain Shameera Syed Rusli ${ }^{1}$, Abdullah Aliff Abdul Wahab ${ }^{1}$, Safirah Jaan Jaafar ${ }^{1}$ and Faiz Daud ${ }^{*}$

\author{
${ }^{1}$ Department of Community Health, Faculty of Medicine, UKM Medical Centre
}

\begin{abstract}
This study primarily intends to determine visitors' perception of leptospirosis health hazard warning signage and its effectiveness within natural recreational parks in the district of Hulu Langat. This cross-sectional study was conducted in four out of seven natural recreational parks, installed with leptospirosis health hazard warning signage. A total of 209 respondents were recruited purposively in this study and completed the questionnaires. Majority of the respondents were male (57.4\%), 40 years old and below (89.5\%), received tertiary education (68.5\%), staying outside Hulu Langat district (83.2\%), visited for the first time (63.6\%), and noticed the presence of leptospirosis health hazard warning signage at the park entrance (69.4\%) and within the recreational park (64.2\%). A significant relationship was discovered between respondents' education level and perception of the health hazard warning signage (p-value o.034). The rate of visits and noticeability of the health hazard warning signage were significantly associated with the effectiveness of the content on the health hazard warning signage (p-value 0.002 and 0.004 , respectively). The construction of health hazard warning signage at the recreational areas should suit the social and educational background of the population. Visitors' discernment of the effectiveness of erecting leptospirosis health hazard warning signage within natural recreational parks in the district of Hulu Langat is good if the signage is perceptible even with subsequent repeated visits to the parks.
\end{abstract}

Keywords: perception; effectiveness; leptospirosis; health; hazard; warning signage; recreational park

\section{INTRODUCTION}

Leptospirosis refers to a zoonotic infection, in which endemicity occurs mostly in tropical regions (Haake \& Levett, 2015). Leptospirosis is caused by Leptospira, a spirochete with the size of $0.1 \mu \mathrm{m}$ in diameter and length of 6 to $20 \mu \mathrm{m}$, which consist of 13 pathogenic and 6 saprophytic species, based on genetic categorisation (Adler \& de la Peña Moctezuma, 2010). Leptospirosis among humans is an outcome from contact with tainted urine, water, or soil from diseased faunae, either directly or indirectly (Garba et al., 2017). The bacteria instigate acute incapacitating infection with fevers, headaches, joint pains, pulmonary haemorrhages, and neurological impairments (Faine et al., 1999). Leptospirosis characterises the intricate connection between the human, the animal host, and the natural setting that transpires in the four main situations where leptospirosis is likely to affect; profession, packed urban setting, recreational exposure, and natural catastrophe (Smith et al., 2013).

Worldwide, 1.03 million cases with 58,900 deaths are estimated to have been caused by Leptospirosis each year (Costa et al., 2015). The World Health Organization (WHO) testified the frequency of leptospirosis occurrence probably ranges from 10 per 1 million population per year in moderate climates, and up to more than 100 per 1 million population 
annually in humid tropical climates, but may reach beyond 1000 per 1 million population should a global endemic occur (World Health Organization, 2012). Leptospirosis has been widespread in this country. The initial reported case in Malaysia involving humans occurred in 1925, among 32 incidents identified among rubber estate workers and populace in rural areas (Fletcher, 1928). Previously, the yearly occurrence of leptospirosis among the Malaysian populace ranged from 1 to 10 per 100,000 of the people. Nevertheless, since the last 10 years, a staggering rise in cases has been reported, with some disease outbreaks mainly associated with recreational outings and natural catastrophes (Benacer et al., 2016, Goh et al., 2019). Meanwhile, in Selangor, the incidence rate of leptospirosis was 39.91\% (second highest after Malacca) in 2012 and 2013 with a 0.42 rate of mortality per 100,000 population (Tan et al., 2016). Leptospirosis cases in the district of Hulu Langat cases were reported to be 599 in 2013, with the Hulu Langat subdistrict as the fourth highest among other subdistricts ( 46 cases). The occurrence of leptospirosis showed the highest cases for July, October, and November of the same year (Zulfikli et al., 2016).

Recreational activities may contribute to leptospirosis by bringing human closer to the leptospiral contaminated environment. In Malaysia, studies showed the existence of pathogenic Leptospira spp. in the soil and the water samples primarily obtained from waterfalls (Azali et al., 2016; Pui et al., 2017). Hence, recreational activities such as swimming, fishing, kayaking, and rafting could raise the threat of leptospirosis infection. The outbreak of human leptospirosis could possibly occur during these high risk activities, evidenced by the presence of positive samples for pathogenic Leptospiral spp. in soils and water taken from several popular recreational areas in Malaysia (Ismail et al., 2014). The leptospiral contamination is postulated originating from the wildlife animals such as rodents that are attracted to left-over foods due to poor hygienic practices in the recreational areas and further pollute the soils and water (Mohamed-Hassan $e t$ al., 2012).

Creating effective public awareness by health promotion strategy could be part of preventive and control measure in tackling this public health issue. Identification of contaminated area where leptospirosis is anticipated should be prioritized, and risk communication for related public need to be done effectively. The Malaysian health authority has put efforts of providing leptospirosis health hazard warning signage in natural recreational parks since 2011 (Lokman, 2011). Nonetheless, the effectiveness of health campaign endeavours and regulation measures, such as prevalent health hazard warning signage, are debatable. Presently, no study has been conducted in Malaysia with regard to visitors' perception of leptospirosis health hazard warning signage within natural recreational parks. Therefore, this study's primary intent is to determine visitors' perception of the effectiveness of leptospirosis health hazard warning signage within natural recreational parks in the district of Hulu Langat, and to ascertain the determining factors linked with the visitors' perception. The findings from this study may benefit relevant authorities such as district health offices (Ministry of Health (MOH) Malaysia), district offices (State Government), and the Ministry of Tourism, Arts and Culture Malaysia (MOTAC) toward revamping the efforts of placing health hazard warning signage for leptospirosis in recreational parks to avert leptospirosis infection related to recreational activities.

\section{MATERIALS AND METHOD}

\section{A. Study location Background}

This cross-sectional study was conducted in natural recreational parks located in the Hulu Langat district of Selangor, Malaysia (Figure 1) from September 2019 to November 2019. The district of Hulu Langat land area is 840 $\mathrm{km}^{2}$ and is Selangor's fifth largest district with a population density of 1.1 million (Pejabat Daerah/Tanah Hulu Langat, 2018). Hulu Langat is a district which blended with urban and rural country residency and the nearest (approximately $25 \mathrm{~km}$ ) to the Malaysian capital in Kuala Lumpur, as compared to the other districts of Selangor. It is managed by the Ampang Jaya Municipal Council and the Kajang Municipal Council. There are 15 natural recreational parks of body surface water in Hulu Langat district (latest update was in 2019) in which seven of it are equipped with leptospirosis hazard warning signage, provided by the Hulu Langat district health office (Tourism Selangor, 2019). A water surface can be described as a distinct and noteworthy component of 
bodies of water, such as lakes, reservoirs, streams, or rivers (Europe Commission, 2009). Four out of seven natural recreational parks, which are equipped with the leptospirosis health hazard warning signage, were conveniently selected due to distance, transportation cost and the number of visitors. The included natural recreational parks are Chongkak River Recreational Forest $\left(3^{\circ} 12^{\prime} 32.03 " \mathrm{~N}\right.$, $\left.101^{\circ} 50^{\prime} 36.64^{\prime \prime E}\right), \quad$ Pangsun River $\quad\left(3^{\circ} 12^{\prime} 23.01 " \mathrm{~N}\right.$, $\left.101^{\circ} 52^{\prime} 47.67^{\prime E}\right), \quad$ Gabai River Waterfall $\left(3^{\circ} 9^{\prime} 20.14 " \mathrm{~N}\right.$, $101^{\circ} 54^{\prime} 33.70^{\prime \prime E}$ ), and Tekala River Recreation Forest $\left(3^{\circ} 3^{\prime} 29.18^{\prime \prime} \mathrm{N}, 101^{\circ} 52^{\prime} 21.36 " \mathrm{E}\right)$ (US Department of State Geographer, 2020).

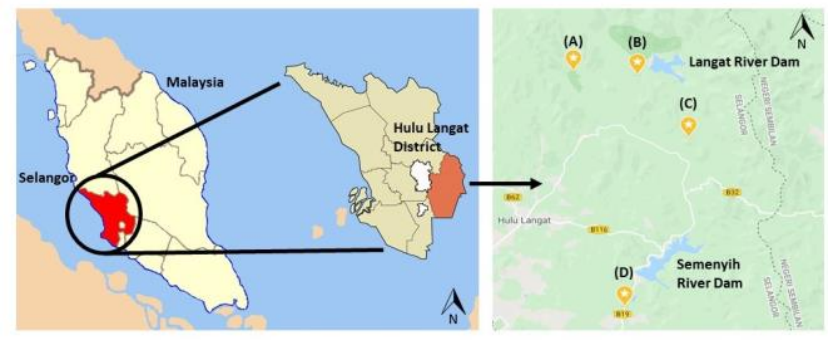

Figure 1. Study locations: (A) Chongkak River Recreational Forest - 3okm from Cheras, Kuala Lumpur; (B) Pangsun River - 22km from Cheras, Kuala Lumpur; (C) Gabai River Waterfall - 23km from Cheras, Kuala Lumpur; and (D) Tekala River Recreation Forest - 33km from Cheras, Kuala Lumpur.

\section{B. Leptospirosis Health Hazard Warning Signage}

A standard leptospirosis health warning hazard signboard has been selected as the physical apparatus to evaluate visitors' perception of the effectiveness of the health warning signage (Figure 2 and Figure 3). These signages were in good condition and erected at 1.5 meters from ground level at the parking area, park entrance and within the recreational park hot spot area. The signboard is written in black and red letter with white and yellow background. The photographic information from the signage consists of six messages to the readers; 1) possible leptospirosis contaminated area, 2) avoidance of swimming if there is a skin wound, 3 ) avoidance to drink untreated water, 4) seek for treatment if develop leptospirosis symptom, 5) self-clean after outdoor activities, and 6) littering etiquettes.

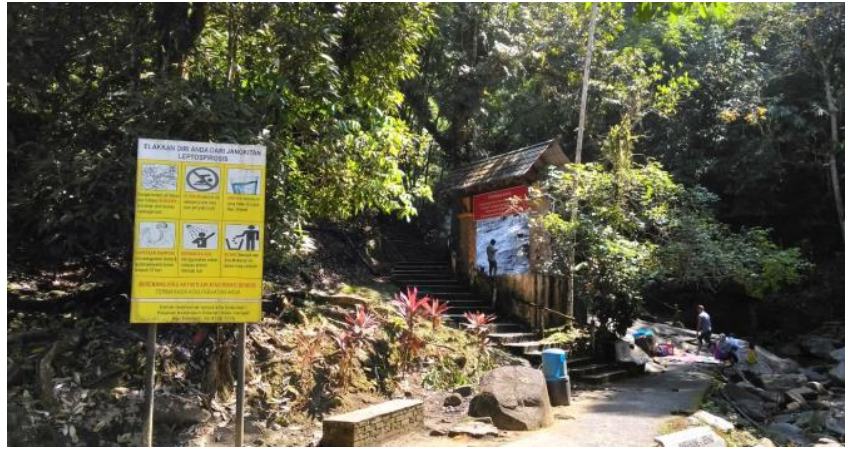

Figure 2. Leptospirosis health hazard warning signage within the area of recreational parks in Hulu Langat district that is used in the study

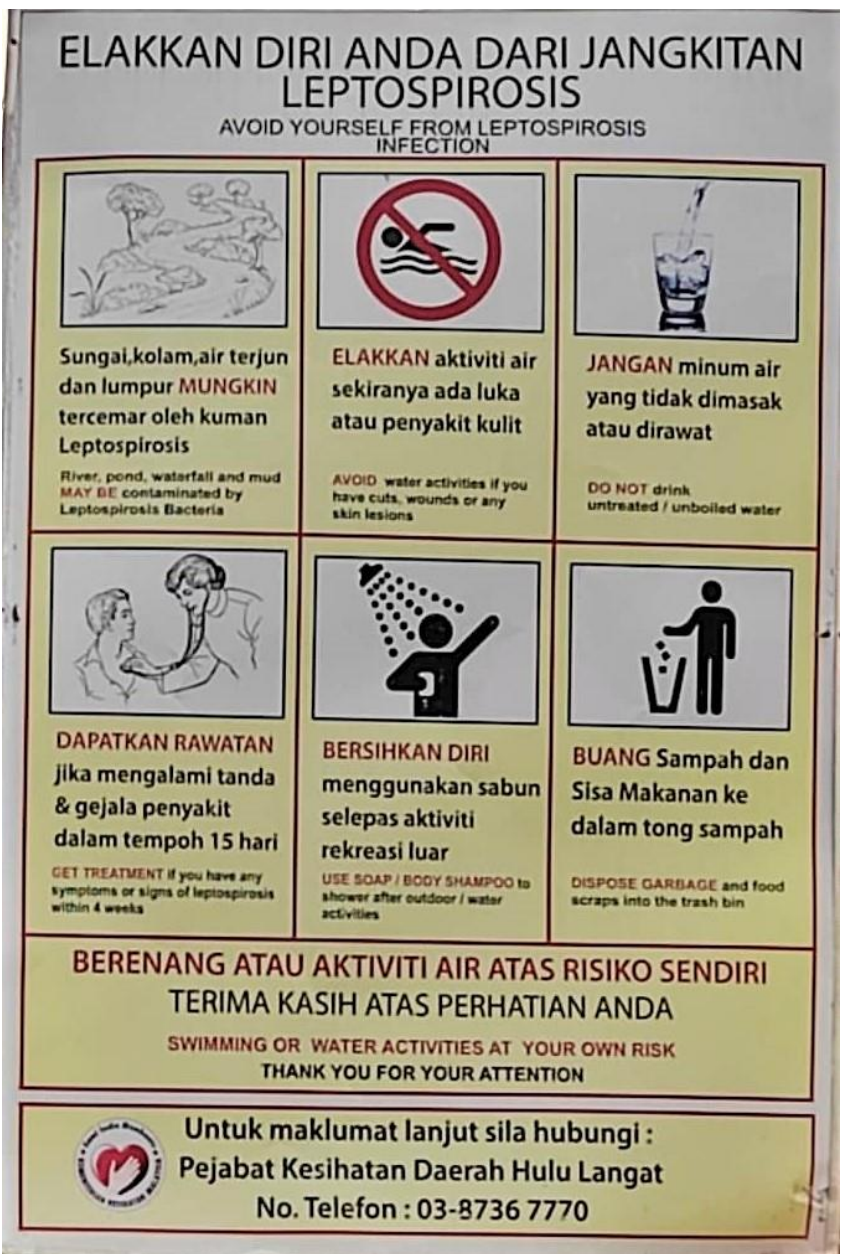

Figure 3. Leptospirosis health hazard warning signage closeup view

\section{Instrument Used to Assess Perception towards Leptospirosis Health Hazard Warning Signage}

The questionnaire was developed and consists of 3 sections; Section A - sociodemographic background of the visitor, Section B3 - information regarding health hazard warning signage and the effectiveness of the indicator's characteristic 
which consisted of 15 questions, and Section C1 - visitor's perception toward the leptospirosis health hazard warning signage which consisted of 10 questions (Table 1). The rating for section B3 and C1 were measured using Likert scale of five (Strongly disagree, disagree, not sure, agree, strongly disagree). The minimum score for section $\mathrm{B}_{3}$ and section $\mathrm{C}_{1}$ were 15 and 10 respectively, while the maximum score for section $\mathrm{B}_{3}$ and section $\mathrm{C} 1$ were 75 and 50, respectively. The main purpose of determination of cut-off points was to divide the scoring into 2 categories of effectiveness of the signage (effective or ineffective signage) and 2 categories of perception (good or bad perception). The cut-off points for section $\mathrm{B}_{3}$ and section $\mathrm{C}_{1}$ were calculated using the formula (1).

$$
\text { C }=\text { MaxRespScore }- \text { MinRespScore }+ \text { MinRespScore (1) }
$$

Where, $\mathrm{C}=$ Cut-off point value

MaxRespScore $=$ Maximum respondent's score

MinRespScore $=$ Minimum respondent's score

Table 1. Statement for items in section $\mathrm{B} 3$ and $\mathrm{C} 1$

\begin{tabular}{|c|c|}
\hline $\begin{array}{l}\text { Item } \\
\text { No. }\end{array}$ & $\begin{array}{l}\text { Section B3 (The effectiveness of the } \\
\text { indicator's characteristic) }\end{array}$ \\
\hline B3-1 & $\begin{array}{l}\text { Health hazard warning signage has warning words. } \\
\text { Example: DANGER! CAUTION! WARNING! }\end{array}$ \\
\hline B3-2 & $\begin{array}{l}\text { The health hazard warning signage does not clearly } \\
\text { describe the disease. }\end{array}$ \\
\hline B3-3 & $\begin{array}{l}\text { The available message explains the effect of non- } \\
\text { compliance on the health hazard warning signage. }\end{array}$ \\
\hline B3-4 & $\begin{array}{l}\text { The message on the health hazard warning signage } \\
\text { does not explain the disease prevention measures. }\end{array}$ \\
\hline B3-5 & $\begin{array}{l}\text { The health hazard warning signage is clearly } \\
\text { visible. }\end{array}$ \\
\hline B3-6 & $\begin{array}{l}\text { The health hazard warning signage is in an } \\
\text { inappropriate location. }\end{array}$ \\
\hline B3-7 & $\begin{array}{l}\text { The health hazard warning signage is compelling to } \\
\text { read. }\end{array}$ \\
\hline B3-8 & The health hazard warning signage is small in size. \\
\hline B3-9 & $\begin{array}{l}\text { The health hazard warning signage has a bright } \\
\text { colour. }\end{array}$ \\
\hline $\mathrm{B}_{3}-10$ & $\begin{array}{l}\text { The number of health hazard warning signage at } \\
\text { this recreation park is not sufficient. }\end{array}$ \\
\hline B3-11 & $\begin{array}{l}\text { The message displayed by the health hazard } \\
\text { warning signage is easy to read. }\end{array}$ \\
\hline
\end{tabular}

Is the message on the health hazard warning signage reliable?

C1-2 Health hazard warning signage does not have complete information.

C1-3 The health hazard warning signage has an up-todate information.

C1-4 I will not obey any instructions or messages that are displayed on the health hazard warning signage.

C1-5 Health warning signage is an appropriate channel to convey health hazard warning messages at recreation park.

There is no evidence that the health hazard warning signage at the recreation park has been endorsed by the respected authority

The message displayed on the health hazard warning signage is appropriate in providing the relevant information.

-8 Is the message displayed by the health hazard warning signage not useful to you?

If the same health hazard warning signage need to be placed in another recreation park, does the content need to be changed?

C1-10 Health hazard warning signage has more than one recurring message or the same meaning.

\section{Procedure}

A total of 209 respondents were selected purposively in four natural recreational parks due to; no registration system at the park entrance, unpredictable time trend of visit, and the variety of visitors such as a group of family, friends, or organization. During the selection of the respondents, the researchers chose adult of both genders, age of 18 years old and above, mentally competent, and capable in terms of literacy and numeracy. Colour-blindness and other forms of 
visual impairment were excluded from the study. Informed consent was taken before the administration of questionnaire. The questionnaire used was self-administered and assisted by the researcher when needed. If the respondents were unaware of leptospirosis health hazard warning signage erected in the study area, they will be shown a picture of a similar signage to guide them to answer the questionnaire. This study was approved by National University of Malaysia (UKM) Research Ethics Committee (UKM PPI/111/8/JEP-2018-274).

\section{E. Data Analysis}

The analysis of data had been accomplished by applying the Statistical Package for Social Sciences (SPSS) version 22. Every respondent's demographic factors and suggestions to improve the existing health hazard warning were computed for frequency and percentage. Chi-Square test was applied to establish the relationship between the factors (qualitative variables) and the outcome (qualitative variables). In the multivariate analysis, multiple logistic regression was applied to ascertain the factors (age, gender, ethnicity, education level, occupation, origin of visitors, frequency of visits, and indicator noticeability) linked to the outcome (effectiveness of health hazard warning signage). A p-value of less than 0.05 was regarded as statistically significant. Detailed statistical analyses were presented in the form of text, tables and figures.

\section{RESULT AND DISCUSSION}

\section{A. Characteristic of the Respondents}

There were a total of 209 visitors participated in this study (Table 2), consisting of $57.4 \%$ males and $42.6 \%$ females. Most of the respondents were 40 years old and below (89.5\%), Malay (92.8\%) and had higher education level (68.5\%). The respondents' occupations varied, but most of them were students (36.4\%). Majority of the respondents came from outside Hulu Langat district (83.2\%) and were first time comers to the recreational area (63.6\%). About $69.4 \%$ of respondents noticed the health hazard warning signage at the entrance and $61.2 \%$ within the recreational area, respectively. Regarding the messages on the health hazard warning signage, $76.6 \%$ of the respondents thought that the signages were effective in advising the information about the disease to the visitors. Whereas, about $78.9 \%$ of them had a good perception of the health hazard warning signage.

Table 2. Respondents' characteristics

\begin{tabular}{|c|c|}
\hline Parameters & n (Percentage) \\
\hline \multicolumn{2}{|l|}{ Age } \\
\hline 40 years and below & $187(89.5 \%)$ \\
\hline More than 40 years & $22(10.5 \%)$ \\
\hline \multicolumn{2}{|l|}{ Gender } \\
\hline Male & $120(57.4 \%)$ \\
\hline Female & $89(42.6 \%)$ \\
\hline \multicolumn{2}{|l|}{ Ethnicity } \\
\hline Malay & $194(92.8 \%)$ \\
\hline Non-Malay & $15(7.2 \%)$ \\
\hline \multicolumn{2}{|l|}{ Education level } \\
\hline Primary school & $15(7.4 \%)$ \\
\hline Secondary school & $49(24.1 \%)$ \\
\hline College/University & $139(68.5 \%)$ \\
\hline \multicolumn{2}{|l|}{ Occupation } \\
\hline Being employed & $55(26.3 \%)$ \\
\hline Self-employed & $29(13.9 \%)$ \\
\hline Housewife & $16(7.7 \%)$ \\
\hline Retired & $4(1.9 \%)$ \\
\hline Student & $76(36.4 \%)$ \\
\hline Others & $23(11.0 \%)$ \\
\hline \multicolumn{2}{|l|}{ Place of residence } \\
\hline Hulu Langat district & $33(15.8 \%)$ \\
\hline Outside Hulu Langat district & $174(83.2 \%)$ \\
\hline \multicolumn{2}{|l|}{ Frequency of visits } \\
\hline First time & $133(63.6 \%)$ \\
\hline Multiple times & $75(35.9 \%)$ \\
\hline \multicolumn{2}{|l|}{ Signage noticeability } \\
\hline \multicolumn{2}{|l|}{ At entrance } \\
\hline Yes & $145(69.4 \%)$ \\
\hline No & $62(29.7 \%)$ \\
\hline \multicolumn{2}{|l|}{ Within the recreational area } \\
\hline Yes & $128(61.2 \%)$ \\
\hline No & $77(36.8 \%)$ \\
\hline \multicolumn{2}{|l|}{ Effectiveness of the health hazard } \\
\hline warning signage & $160(76.6 \%)$ \\
\hline Yes & $47(22.5 \%)$ \\
\hline \multicolumn{2}{|l|}{ No } \\
\hline \multirow{2}{*}{\multicolumn{2}{|c|}{$\begin{array}{l}\text { Perception of the visitors towards } \\
\text { health hazard warning signage }\end{array}$}} \\
\hline & \\
\hline Good & $165(78.9 \%)$ \\
\hline Bad & $42(20.1 \%)$ \\
\hline
\end{tabular}




\section{B. Respondents' Suggestions to Improve the Existing Health Hazard Warning Signage}

The most observed suggestion recommended by the respondents was to increase the overall number of the health hazard warning signage (Table 3). These respondents also thought that the colours used in the signage were not striking and intriguing enough to attract visitors' attention. Other suggestions among others included to change the location of the signage, renew the overall condition, increase font size, add more pictures and explanation besides using simpler words and terminology. Some respondents also suggested to include MOH logo, add more language and use digital signage.

Table 3. Respondents' feedback and suggestions to improve the existing health hazard warning signage $(n=67)$

\begin{tabular}{lc}
\hline \multicolumn{1}{c}{ Feedbacks/Suggestions } & n (Percentage) \\
\hline Increase the number of signage & $12(17.9 \%)$ \\
Change to more striking colour, & $12(17.9 \%)$ \\
example red & $10(14.9 \%)$ \\
Increase the size of signage & $9(13.4 \%)$ \\
Change the location of the signage to & \\
more noticeable area, example & \\
parking area, exit and entrance, & \\
within the recreational area & $6(9.0 \%)$ \\
Renew the overall condition & $6(9.0 \%)$ \\
Increase the font size & $5(7.5 \%)$ \\
Add more pictures & $3(4.5 \%)$ \\
More explanation, use simpler & \\
words/terminology & $1(1.5 \%)$ \\
No warning sign & $1(1.5 \%)$ \\
Change to digital signage & $1(1.5 \%)$ \\
Add Ministry of Health (MOH) logo & $1(1.5 \%)$ \\
Add more language &
\end{tabular}

\section{Relationship between Factors and Outcomes}

From the bivariate analysis, no significant relationship was obtained between the frequency of visits to the park and the noticeability of the health hazard warning signage at the park entrance (p-value 0.772) and within the park area (p-value 0.464) (Table 4). There was no significant relationship discovered between respondents' education level and the effectiveness of the content on health hazard warning signage (p-value o.751) (Table 5), indicating that health hazard warning signage is effective as the 'warning message' was able to be understood by people from all education background. However, there was a significant relationship was discovered between respondents' education level and their perception of the health hazard warning signage (p-value o.o34) (Table 6). In the multivariate analysis (Table 7), it was found that the frequency of visits and noticeability of the health hazard warning signage were the significant determining factors for the effectiveness of messages on the health hazard warning signage (p-value 0.001 and 0.007 , respectively). Regular visitors showed a $74 \%$ better perception of the effectiveness of leptospirosis health hazard warning signage compared to first time visitors $(\mathrm{OR}=0.267, \mathrm{p}$-value $=0.001(\mathrm{CI} 95 \% 0.126$, 0.566). The visitors who noticed the leptospirosis health hazard warning signage were 2.7 times higher to perceive those signages as effective, compared to those who did not notice the signage $(\mathrm{OR}=2.685, \mathrm{p}$-value $=0.007$ (CI 95\% $1.318,5 \cdot 911)$.

Table 4. Association between frequency of visits and noticeability of the health hazard warning signage

\begin{tabular}{|c|c|c|c|}
\hline \multirow[t]{3}{*}{ Factors } & \multicolumn{2}{|c|}{ Outcomes } & \multirow{3}{*}{$\begin{array}{c}\text { p- } \\
\text { value }\end{array}$} \\
\hline & $\begin{array}{l}\text { Noticeabilit } \\
\text { entrance, } n\end{array}$ & $\begin{array}{l}\text { of signage at } \\
\text { percentage) }\end{array}$ & \\
\hline & Yes & No & \\
\hline \multicolumn{4}{|l|}{$\begin{array}{l}\text { Frequency of } \\
\text { visits }\end{array}$} \\
\hline First time & $92(69.7 \%)$ & $40(30.3 \%)$ & 0.772 \\
\hline \multirow[t]{2}{*}{ Multiple times } & $53(71.6 \%)$ & $21(28.4 \%)$ & \\
\hline & \multicolumn{2}{|c|}{$\begin{array}{c}\text { Noticeability of signage } \\
\text { within park area, } \mathrm{n} \\
\text { (percentage) }\end{array}$} & \\
\hline \multicolumn{4}{|l|}{$\begin{array}{l}\text { Frequency of } \\
\text { visits }\end{array}$} \\
\hline First time & $84(64.6 \%)$ & $46(35.4 \%)$ & 0.464 \\
\hline Multiple times & $44(59.5 \%)$ & $30(40.5 \%)$ & \\
\hline
\end{tabular}


Table 5. Association between education level and effectiveness of the health hazard warning signage

\begin{tabular}{|c|c|c|c|}
\hline \multirow[t]{3}{*}{ Factors } & \multicolumn{2}{|c|}{ Outcomes } & \\
\hline & \multicolumn{2}{|c|}{$\begin{array}{c}\text { Effectiveness, n } \\
\text { (percentage) }\end{array}$} & \\
\hline & Yes & No & \\
\hline \multicolumn{4}{|l|}{$\begin{array}{l}\text { Education level } \\
\text { (n) }\end{array}$} \\
\hline Primary school & $12(80.0 \%)$ & $3(20.0 \%)$ & \\
\hline Secondary school & $36(73.5 \%)$ & $13(26.5 \%)$ & 0.751 \\
\hline $\begin{array}{l}\text { College/ } \\
\text { University }\end{array}$ & 109 (78.4\%) & $30(21.6 \%)$ & \\
\hline
\end{tabular}

Table 6. Association between education level and visitor's perception towards the health hazard warning signage

\begin{tabular}{lccc}
\hline \multicolumn{1}{c}{ Factors } & \multicolumn{2}{c}{ Outcomes } & $\begin{array}{c}\text { p- } \\
\text { value }\end{array}$ \\
\hline & \multicolumn{2}{c}{$\begin{array}{c}\text { Perception, n (percentage) } \\
\text { Good }\end{array}$} & Bad \\
Education level & & & \\
Primary school & $8(53.3 \%)$ & $7(46.7 \%)$ & $\mathbf{0 . 0 3 4}{ }^{*}$ \\
$\begin{array}{l}\text { Secondary } \\
\text { school }\end{array}$ & $39(79.6 \%)$ & $10(20.4 \%)$ & \\
College/ & $114(82.0 \%)$ & $25(18.0 \%)$ & \\
University & & & \\
\hline
\end{tabular}

\section{Effectiveness of the Health Hazard Warning Signage}

The effectiveness was measure in terms of the warning slogan, explanation of the health hazard, health consequence of the hazard and related preventive measures. Since perception is a behavioural component that associate with the past experience, language understanding, and cultural background, the effectiveness of the health hazard warning signage (which influence perception) is also related to the visual effect of the signage (colour contrast, infographic, font size, or word length), the content of warning (layman versus medical term), the location of signage installation, and the attractiveness of the signage design (appearance of a role model in the signage, digitalized signage, or signage lighting).

\section{E. Definition of Perception}

The verb 'to perceive' traced its origin from the Latin word percipere; the morpheme per means 'through' while the morpheme capere means 'to take'. This definition denotes an interaction between natural stimuli and a person's comprehension, allowing for the ability to perceive. The noun 'perception' has extra descriptions, namely comprehension, knowledge obtained from observation, or specific ideas, concepts, impressions, etc. The descriptions above infer that both the natural stimuli and the internal process are adequate and essential components required for perception (Bunting, 1988).

Perception is also referred to as the individual beliefs about his or her health condition that ultimately determine the behaviour of people towards health conditions or health promoting activities. Health belief model explains the components perception which is perceived susceptibility; the persons belief they can get the disease, perceived severity; the person belief the health condition has consequences, perceive benefit; the person belief that the bad outcome can be prevented if action taken and perceive barrier; the person will not adopt the preventive behaviour if they belief there is a lot of obstacles (Carpenter, 2010). In this study, the leptospirosis health hazard warning signages are the communicative tools to alert the visitors of recreational area on the risk of leptospirosis infection. When a person belief that anyone can become infected with leptospirosis and can develop complications if untreated, there is specific treatment for the disease, the person most likely will have good perception on the effectiveness of the health warning signage.

Perception depends on the combination of both knowledge and awareness of the subject matter; in which educational level of the respondents may only contributed to the knowledge component towards the subject, but the message conveyed through the communication tools, in this case, the leptospirosis health hazard warning signage has not been able to raise the recipients' awareness (among the visitors who come to recreational parks). Knowledge on the facts concerning leptospirosis, the associated health effects, and the presence of symptoms should signal the recipients to obtain medical treatment, or to take precautionary measures to avert any potential threat. Since perception is unique to one's experience, respondents can only visualize from what is 
known to one-self in the form of emotion and past experience (Walker \& Avant, 2005).

\section{F. Factors Associated with the Perception of the Effectiveness of Leptospirosis Health Hazard Warning Signage}

Education level was found significantly influence the perception of visitors towards the health hazard warning signage when stand alone, but after adjusted with all the other confounders, it becomes not significant. Hence, the perception of the health hazard warning signage may not be due to the signage itself, but a prior conception towards the health hazard. This could also be due to most respondents who administered the questionnaire were from among those at higher level of education such as college and university during the day of sampling.

The perception of effectiveness of leptospirosis health hazard warning signage set up at recreational parks in the district of Hulu Langat, Selangor, substantively correlated with the number of visits to recreational parks and visitors' observability of the signage within the park areas. The reflection of this finding serves as a proxy to measure that repetitive visual cues will eventually draw the attention of the recipients towards the signage erected within the area of visit, regardless of the suitability of the site of erection, size of the signboard, attractiveness of the signage or the effectiveness of the educational message about the subject 'leptospirosis', because frequent visitors are well versed with the site of visit, being more attentive to even slight changes in the area, including the presence of a health hazard warning signage, which may attract them to stop by and read the content of the signage (Hwang et al., 2011). Nevertheless, other studies showed that people who visit a place frequently and familiar with the surrounding environment of the place are less expected to read any signage that inform regarding possible hazard from the environment (Laughery \& Wogalter, 2014).

Noticeability to health hazard warning signage can be limited by visual appearance of the signage, and whether the signage is understandable or not for the visitors. Therefore, the health hazard warning signage for leptospirosis prevention in recreational park should be designed in appropriate location, size, and shape, attractive colour contrast and format of the text (Hwang et al., 2011). From the findings, the entrance is the most suitable location for placement of the signage, compared to placing them within the recreational area. This is probably due to the visitors are usually trying to get information about the park at the entrance whereas they are distracted and more interested on the activities when they are in the recreational area (Laughery \& Wogalter, 2014). The signage should be placed at location that are visible to the visitors, must be at eye level and not obstructed from the visitor's view (trees, bushes, and other structures) (Laughery \& Wogalter, 2014). The colour of the signage should be contrast with the surrounding environment to enhance visibility especially for visitors who have visual impairment, colour blindness and older adults with presbyopia who has difficulties in differentiate colours (Laughery \& Wogalter, 2014). Some studies show that women and older people are more likely to notice the warning signage compared to other groups of visitors (Wogalter, 2006). However, our findings did not support the previous findings as there was no difference in noticeability of the signage among age groups and gender. Creating signage that are easily understood is a straightforward method in increasing the healthcare awareness of individuals with low literacy, health knowledge, or language competence (Rudd \& Anderson, 2006), which includes:

1. Use simple, familiar, everyday words.

2. Ensure signs are easily read, clearly noticeable, and have a constant format.

3. Other languages to be included on signs, especially the main languages spoken in the population.

4. Use the symbols consistently in other forms of written information such as printed handouts, service directories or website to help visitors familiarize with the symbols.

5. Regulate the number and range of warning signs in communicating processes, procedures, and other instructions.

\section{G. Importance of Health Hazard Warning Signage}

The function of health hazard warning signage is to deliver information, to shape behaviour, and to forewarn (Laughery \& Wogalter, 2014). The health hazard warning signage that encompass words and symbols can increase noticeability and influence visitors' behaviour. For example, a picture of rats near left-over food and a picture of sick people can influence 
visitors to avoid littering at the inappropriate place in the park. The health hazard warning signage in these recreational parks also can be a reminder to those who have dormant knowledge about leptospirosis. It will give cue to important information; thus, leading to an awareness of the hazard.

\section{H. Risk Communication}

Risk communication is crucial to ensure that the public or the population understand and aware of the hazard that may affect their health, and subsequently take immediate and appropriate action. A study of the awareness and information on leptospirosis was conducted in the district of Hulu Langat, Selangor, in 2018 revealed that most participants (87.4\%) had some knowledge on the 'rat-urine disease'. Many participants (75.5\%) acknowledged mass media, such as radio and television, as the primary informational sources. Nearly half (51.0\%) of the participants obtained information via newspapers, whereas $17.8 \%$ and $15.5 \%$ acquired the details via doctors and magazines, respectively (Nozmi et al., 2018). The disease, which is popularly known as 'rat-urine disease' has been acknowledged for many years in the local community since the term has been depicted as sensational news by Malaysian broadcasting media in headlines regarding multiple incidents which involved camping enthusiasts, rescue workers, and military personnel (Hin et al., 2012). Nevertheless, due to the fact that other mammals also cause leptospirosis, not limited to infected rodents, precise details need to be disseminated toward a wellinformed comprehension of the disease so that efficient precautionary approaches can be executed. The Malay language used in the leptospirosis signage as a medium of communication has not become a barrier of communication to the public. In this study, we found that the Hulu Langat district health office used the term 'leptospirosis' instead of rat-urine disease. Perhaps, the health district office has the purpose to educate and familiarize the public about the correct and precise terminology. The information about leptospirosis also can be delivered to the public via risk-based analysis, in which the status of recreational center can be divided into high risk (red zone), moderate risk (yellow zone) and low risk (green zone) based on the number of active cases and mortality cases. The information about the risk should also be shared and discussed with the expert from the veterinary field to keep the information updated and strategize health education and other forms of health intervention (Sulaiman et al., 2020).

A comprehensive communication for the purpose of intervention must be regarded as highly crucial when planning to design health communication or social marketing campaigns. The target population must be necessarily understood, so that the content creation is germane and applicable. Messages should be tailored specifically to the communication channel being utilised. Moreover, the use of multiple communication and media strategies will guarantee a wider spread. Additionally, the target population's access to the various communication channels in use, must be ensured and improved if necessary.

\section{Recommendation to Improve the Leptospirosis Health Hazard Warning Signage}

Majority of the recommendation made by respondent is to increase the number of health hazard warning signages at the recreational area. More signages placed at suitable location at the recreational area could lead to increase noticeability by the visitors, therefore increase its effectiveness. The signage should be placed at strategic places such as the parking area, entrance or toilets of the recreational areas, where first time visitors can be made aware of. On the other hand, dull and less colour contrast of the signage can reduce the attractiveness of the health warning signage, especially to the people with visual impairment and colour blind (Rousek \& Hallbeck, 2011). Therefore, the signage should be designed with appropriate colour contrast that allows its recognition by all visitors from far distance and improves comprehension to the signage (Rousek \& Hallbeck, 2011).

The construction of health hazard warning signage at recreational area should suit the social and educational background of the population who are Malaysian, Malay ethnicity, men, age of 40 years old and below, college and university students. The font size of the wording should be larger to capture attention of the first timer. Plain, long explanation of the risk and consequences can be replaced with simple tag-line jargon that can capture the attention of students and working adult in Selangor or suit to local culture. The visual cues for symptoms of leptospirosis such as joint pain, conjunctivitis, fever should be replaced by simple pictogram for easier visualization from far. These measures 
can aid in memory and experience recall to awareness towards the health hazard, hence improving perception of the recipients. For instance, seeing a pictogram of a rat in the river can help recipients to recall past memory of witnessing a rat running through their house or recall the urine smell of the rat, hence improve perception that a prevention measure should be practiced, such as do not swim with open wounds in the river and proper littering.

\section{J. Limitation}

A good perception level on the effectiveness of health hazard warning signage, which are erected at the recreational area, reflects that the health hazard warning signage is effective in conveying health messages to the general public. However, cautious interpretation of the perception of health hazard warning signage and its effectiveness is required, as when perception is not directly due to the signage erected, but a prior knowledge and awareness, perception of the effectiveness of signage is relative. The sampling bias is unavoidable due to method of purposive sampling among respondents who were present at the recreational park of visit during the weekend. Local resident who stay nearby the recreational park usually would not visit the park during peak season to avoid congestion. The presence of both researchers (with specific professional attire) can influence the perception of the visitors towards a health hazard and may lead to social desirability bias (Dodou \& de Winter, 2014). This happened when researchers alerted the visitors by showing them where the signage was after they had admitted to not have seen the signage, then guided them to screen through the signage in the near distance.

\section{CONCLUSION}

In conclusion, the perception of the effectiveness of leptospirosis health hazard warning signage at recreational parks in the district of Hulu Langat, Selangor, is beneficial when signage is noticeable, especially after repeated visits to the parks. Nevertheless, cautious interpretation of the signage effectiveness perception is required, and the perception of signage effectiveness should be triangulated with evaluation of signage effectiveness based on relevant epidemiological data (morbidity and mortality of leptospirosis) on leptospirosis within the district after the erection of health hazard warning signage at the recreational parks.

\section{ACKNOWLEDGEMENT}

The authors would like to express thanks and appreciation to the Department of Community Health, Faculty of Medicine, National University of Malaysia for providing assistance toward the completion of this research. This research study was self-funded and approved by National University of Malaysia (UKM) Research Ethics Committee (UKM PPI/111/8/JEP-2018-274) with project code: FF-2018-277.

\section{REFERENCES}

Adler, B \& de la Peña Moctezuma, A 2010, 'Leptospira and leptospirosis', Veterinary Microbiology, vol. 140, no. 3-4, pp. 287-296.

Azali, MA, Yean Yean, C, Harun, A, Baki, A, Najian, N \& Ismail, N 2016, 'Molecular characterization of Leptospira spp. in environmental samples from north-eastern Malaysia revealed a pathogenic strain, Leptospira alstonii', Journal of Tropical Medicine, vol. 2016.

Benacer, D, Thong, KL, Min, NC, Verasahib, KB, Galloway, RL, Hartskeerl, RA, Souris, M \& Zain, SNM 2016, 'Epidemiology of human leptospirosis in Malaysia, 20042012', Acta Tropica, vol. 157, pp. 162-168.
Bunting, SM 1988, 'The concept of perception in selected nursing theories', Nursing Science Quarterly, vol. 1, no. 4, pp. 168-174.

Carpenter, CJ 2010, 'A meta-analysis of the effectiveness of health belief model variables in predicting behavior', Health Communication, vol. 25, no. 8, pp. 661-669.

Costa, F, Hagan, JE, Calcagno, J, Kane, M, Torgerson, P, Martinez-Silveira, MS, Stein, C, Abela-Ridder, B \& Ko, AI 2015, 'Global morbidity and mortality of leptospirosis: a systematic review', PLoS Neglected Tropical Diseases, vol. 9, no. 9, pp. eooo3898. 
Dodou, D \& de Winter, JC 2014, 'Social desirability is the same in offline, online, and paper surveys: a meta-analysis', Computers in Human Behavior, vol. 36, pp. 487-495.

Europe Commission 2009, Common implementation strategy for the water framework directive (2000/60/EC).

Faine, S, Adler, B, Bolin, C \& Perolat, P 1999, Leptospira and leptospirosis, 2nd edn, Medical Science, Melbourne, Victoria, Australia.

Fletcher, W 1928, 'Recent work on leptospirosis, tsutsugamusfai disease, and tropical typhus in the federated malay states', Transactions of the Royal Society of Tropical Medicine and Hygiene, vol. 21, no. 4.

Garba, B, Bahaman, AR, Khairani-Bejo, S, Zakaria, Z \& Mutalib, AR 2017, 'Retrospective study of leptospirosis in Malaysia', EcoHealth, vol. 14, no. 2, pp. 389-398.

Goh, SH, Ismail, R, Lau, SF, Megat Abdul Rani, PA, Mohd Mohidin, TB, Daud, F, Bahaman, AR, Khairani-Bejo, S, Radzi, R \& Khor, KH 2019, 'Risk factors and prediction of leptospiral seropositivity among dogs and dog handlers in Malaysia', International Journal of Environmental Research and Public Health, vol. 16, no. 9, pp. 1499.

Haake, DA \& Levett, PN 2015, 'Leptospirosis in humans', Leptospira and Leptospirosis, vol. 387, pp. 6597.

Hin, HS, Ramalingam, R, Chunn, KY, Ahmad, N, Ab Rahman, J \& Mohamed, MS 2012, 'Fatal co-infection-melioidosis and leptospirosis', The American Journal of Tropical Medicine and Hygiene, vol. 87, no. 4, pp. 737-740.

Hwang, AD, Wang, H \& Pomplun, $M$ 2011, 'Semantic guidance of eye movements in real-world scenes', Vision Research, vol. 51, no. 10, pp. 1192-1205.

Ismail, S, Wahab, NZA, Badya, N, Rahman, NIA, Yeo, CC, Latif, AZA. \& Haque, M 2014, 'A study on the presence of pathogenic Leptospira spp. in environmental water samples obtained from selected recreational areas in Terengganu, Malaysia', Research Journal of Pharmacy and Technology, vol. 7, no. 10, pp 1153 .

Laughery, KR \& Wogalter, MS 2014, 'A three-stage model summarizes product warning and environmental sign research', Safety Science, vol. 61, pp. 3-10.

Lokman, H 2011, Guidelines for the Diagnosis, Management, Prevention and Control of Leptospirosis in Malaysia, Disease Control Division, Ministry of Health Malaysia.

Mohamed-Hassan, S, Bahaman, A, Mutalib, A \& KhairaniBejo, S 2012, 'Prevalence of pathogenic leptospires in rats from selected locations in peninsular Malaysia', Research Journal of Animal Sciences, vol. 6, no. 1, pp. 12-25.
Nozmi, N, Samsudin, S, Sukeri, S, Shafei, M, Wan Mohd, W, Idris, Z, Arifin, W, Idris, N, Saudi, S \& Abdullah, N 2018, 'Low levels of knowledge, attitudes and preventive practices on leptospirosis among a rural Community in Hulu Langat District, Selangor, Malaysia', International Journal of Environmental Research and Public Health, vol. 15, no. 4, pp. 693.

Pejabat Daerah/Tanah Hulu Langat 2018, Latar Belakang Daerah Hulu Langat, viewed 27 Nov 2019, $<$ http://www2.selangor.gov.my/hululangat.php/pages/vie $\mathrm{w} / 125$ ? $\mathrm{mid}=16>$.

Pui, CF, Bilung, LM, Apun, K \& Su'ut, L 2017, 'Diversity of Leptospira spp. in rats and environment from urban areas of Sarawak, Malaysia', Journal of Tropical Medicine.

Rousek, JB \& Hallbeck, MS 2011, 'Improving and analyzing signage within a healthcare setting', Applied Ergonomics, vol. 42, no. 6, pp. 771-784.

Rudd, RE \& Anderson, JE 2006, The Health Literacy Environment of Hospitals and Health Centers, Partners for Action: Making Your Healthcare Facility Literacy-Friendly, National Center for the Study of Adult Learning and Literacy (NCSALL).

Smith, JK, Young, M, Wilson, K \& Craig, S 2013, 'Leptospirosis following a major flood in Central Queensland, Australia', Epidemiology \& Infection, vol. 141, no. 3, pp. 585-590.

Sulaiman HF, Ismail, R, Mohd Yusoff, H, Anuar, N, Mohd Jamil, MR, Daud, F 2020, 'Validation of occupational zoonotic disease questionnaire using fuzzy delphi method', Journal of Agromedicine, vol. 25, no. 2, pp. 166-72.

Tan, WL, Soelar, SA, Mohd Suan, MA, Hussin, N, Cheah, WK, Verasahib, K \& Goh, PP 2016, 'Leptospirosis incidence and mortality in Malaysia', Southeast Asian J Trop Med Public Health, vol. 47, no. 3, pp. 434-440.

Tourism Selangor 2019, What to see in Hulu Langat, viewed $27 \quad$ Nov 2019, $<$ http://www.tourismselangor.my/destination/hululangat-what-to-see/>.

US Department of State Geographer 2020, Google earth pro 7.3.3.7699 (64-bit), viewed 7 May 2020, Data SIO, NOAA, US Navy, NGA, GEBCO.

Walker, LO \& Avant, KC 2005, Strategies for theory construction in nursing, 4th edn, Pearson/Prentice Hall, Upper Saddle River, NJ.

Wogalter, MS 2006, Warnings and aging: describing the receiver characteristics of older adults, Handbook of Warnings, CRC Press, New York, US. 
World Health Organization 2012, Leptospirosis Burden Epidemiology Reference Group (LERG).

Zulfikli, Z, Shariff, ARM \& Tarmidi ZM 2016, 'Human leptospirosis distribution pattern analysis in Hulu Langat, Selangor', in IOP Conference Series: Earth and Environmental Science, 2016. 